\title{
ADDITIONS TO THE COSTA RICAN MYOXANTHUS (ORCHIDACEAE: PLEUROTHALLIDINAE)
}

\author{
GustaVo Rojas-Alvarado ${ }^{1,4}$ \& AdAm P. KarRemans ${ }^{2,3}$ \\ ${ }^{1}$ Regional Postgraduate Program in Biology, University of Costa Rica, P.O. Box 302-7050 Cartago, \\ Costa Rica \\ ${ }^{2}$ Lankester Botanical Garden, University of Costa Rica \\ ${ }^{3}$ Naturalis Biodiversity Center - Leiden University, The Netherlands \\ ${ }^{4}$ Author for correspondence: gustavo.rojasalvarado@ucr.ac.cr

\begin{abstract}
Pleurothallis cerea, a species described based on a specimen collected by Lankester in Costa Rica, and commonly placed under the synonymy of Myoxanthus octomeriae or M. congestus, is here recognized as distinct. The species is easily distinguished by the shape and size of the leaf, as well as various floral details, especially of the lip. A new combination, tentatively suggested by Carl Luer but never published, is required and therefore validated. Additionally, the vegetatively striking Myoxanthus affinis is recorded from Costa Rica for the first time based on two recent collections. The species is variable within its broad distribution from Colombia to Bolivia and, although differences with the original material from Peru are evident, we cannot be sure at this time that ours represents a different species. Both species are described and illustrated based on living plants.
\end{abstract}

KeY WORDS: Carl Luer, Myoxanthus affinis, M. octomeriae, Pleurothallis cerea, taxonomy

Introduction. Myoxanthus (Orchidaceae: Pleurothallidinae) was proposed by Poeppig and Endlicher (1835) to accommodate a species collected by the first author in Peru, Myoxanthus monophyllus Poepp. \& Endl. The genus was, however, soon treated as a synonym of Pleurothallis R. Br. by Lindley (1836), and its only species was transferred to the latter as Pleurothallis poeppigii. The second attempt to propose a new generic name for a species of Myoxanthus was made by Karsten (1847), when he proposed the genus $D u$ boisia, later renamed Duboisia-Reymondia H. Karst. due to a preexisting name in the Solanaceae (Karsten 1848). Both were treated as synonyms of Pleurothallis by Reichenbach (1852). The proposal of Chaetocephala Barb. Rodr. (1882) was the third attempt at recognition for the species of Myoxanthus as segregates from Pleurothallis. But that genus was also placed under Pleurothallis shortly after, on this occasion by Cogniaux (1896).

The situation would remain virtually unchanged for almost a century, and it is not until 1982 that Luer reconsiders this group of species, and segregates them from Pleurothallis. He described one new spe- cies and transferred 33 others to his newly re-circumscribed Myoxanthus, with the previously mentioned Chaetocephala, Duboisia and Duboisia-Reymondia among its synonyms. The establishment of the genus was supported by the anatomical studies made by Pridgeon and Stern (1982). A few years after, Luer (1986) broadened the circumscription of Myoxanthus by transferring Pleurothallis aspasicensis Rchb.f. and Pleurothallis pan Luer, later selected as type species of Myoxanthus subgen. Satyria Luer, and Myoxanthus subgen. Silenia Luer respectively, and their allies to the genus. In his monograph of Myoxanthus, Luer (1992) included 47 species and divided them into three subgenera, Myoxanthus subgen. Myoxanthus (with sections Antenella Luer, Myoxanthus, and Scandentia Luer), Myoxanthus subgen. Satyria, and Myoxanthus subgen. Silenia. The morphological features of the seven members of subgenera Silenia and Satyria were very unlike the species of subgenus Myoxanthus, shedding doubt on their affinities within the genus. Reconsidering his initial interpretation, Luer (1995) transferred the two sections to Pleurothallis subgen. Acianthera (Scheidw.). 
The DNA evidence published by Pridgeon, Solano and Chase (2001) showed that Myoxanthus is indeed not closely related to Pleurothallis, and that it is monophyletic with the exclusion of the species belonging to subgen. Silenia and subgen. Satyria. These two subgenera were finally segregated into a novel generic concept under the name Echinosepala Pridgeon \& M.W Chase (Pridgeon \& Chase 2002). Karremans (2016) suggests that Echinosepala and Myoxanthus are sister genera within the Restrepia affinity, which is the same we have found in our own unpublished analyses, albeit with weak support.

Myoxanthus as defined by Pridgeon (2005) and Karremans (2016) is an easily recognizable and monophyletic genus within the Pleurothallidinae with some 49 accepted species, distributed from southern Mexico, throughout Central America, to Bolivia and Brazil (Luer 1986, 1992). The highest diversity is found in Ecuador (with 25 species), Colombia (14 species), Peru (13 species) and Venezuela (11 species). The genus has one of the broadest altitudinal distributions within the Pleurothallidinae, ranging from $3 \mathrm{~m}$ (in Brazil) to $3200 \mathrm{~m}$ (in Colombia) (Pridgeon 2005), but being more frequent at elevations between 1000 and $2500 \mathrm{~m}$ (Luer 1992).

The plants of Myoxanthus are epiphytes, lithophytes, or occasionally terrestrial, herbs, with caespitose, repent, or scandent habits, characterized by having rhizomes and ramicauls with hispidulous, scurfy sheaths (Luer 1992) with unicellular trichomes arranged in lines perpendicular to the axis of the stem (Pridgeon \& Stern 1982). The sepals are usually fleshy and often pubescent, the laterals usually connate; the petals are usually linear, fleshy or thickened toward the apex, sometimes with osmophores (Luer 1982). The lip is thick, variously shaped, and delicately hinged to a thick column-foot. The column is semiterete, variably winged or toothed, the anther is ventral, with a pair of ovoid pollinia, brought together by a pair a whale-tail like caudicles. The anther cap is cellularglandular, often ciliate, fimbriate or papillose on the upper edge (Luer 1992).

Pupulin (2002) cited seven species of Myoxanthus in his catalogue of the orchids of Costa Rica, whereas Luer (2003) would include only five of them in the Manual de Plantas, and only mentioning Myoxanthus exasperatus (Lindl.) Luer and Myoxanthus trachychlamys (Schltr.) Luer, as cited by the first, but without expressly excluding them. With the later addition of Myoxanthus sotoanum Pupulin, Bogarín \& Mel.Fernández, a new species similar to M. scandens (Ames) Luer, published by Pupulin, Bogarín and Fernández (2010), eight species of Myoxanthus are currently reported for the country. Two additional species are here recognized for the flora of the country, bringing the total to ten. One, Myoxanthus affinis (Lindl.) Luer, is newly reported based on two recent collections, while Pleurothallis cerea Ames, a species described from Costa Rica and commonly placed under the synonymy of Myoxanthus octomeriae (Schltr.) Luer or M. congestus (A. Rich. \& Galeotti) Soto Arenas, is recognized as a distinct species and transferred to Myoxanthus.

\section{Taxonomic treatment}

Myoxanthus affinis (Lindl.) Luer, Selbyana 7: 35. 1982.

Bas.: Pleurothallis affinis Lindl., Companion Bot. Mag. 2: 354. 1837.

Homotypic synonym: Humboldtia affinis (Lindl.) Kuntze, Revis. Gen. P1. 2: 667. 1891.

TYPE: Peru. Dept. of San Martín: Lithophytic, Province of Chachapoyas, 1835, Mathews 1899 (holotype, K; photo of type!; Fig. 1).

Heterotypic synonyms: Pleurothallis rigidifolia Rchb.f., Bonplandia 3: 224. 1855. Humboldtia rigidifolia (Rchb.f.) Kuntze, Revis. Gen. P1. 2: 668. 1891.

TYPE: Peru. Dept. of San Martín: Lithophytic near Chachapoyas, 1840, Mathews 3187 (holotype, G; photo of type!).

Pleurothallis furfuracea F.Lehm. \& Kraenzl., Bot. Jahrb. Syst. 26(3-4): 441. 1899.

TYPE: Ecuador. Prov. of Morona Santiago: Andes east of Sigsig, 1887, F. C. Lehmann 6511 (holotype, K; photo of type!; Fig. 2).

Plant large, epiphytic, densely caespitose. Roots flexuous, branching, 1-2 mm in diameter. Ramicauls stout, erect, up to $70 \mathrm{~cm}$ long, $3-5 \mathrm{~mm}$ in diameter, enclosed by overlapping, tubular sheaths. Sheaths light brown, papyraceous, $6-10 \mathrm{~cm}$ long, covered by trichomes except the uppermost, trichomes dark, disposed in rows perpendicular to the ramicaul axis. Leaf 


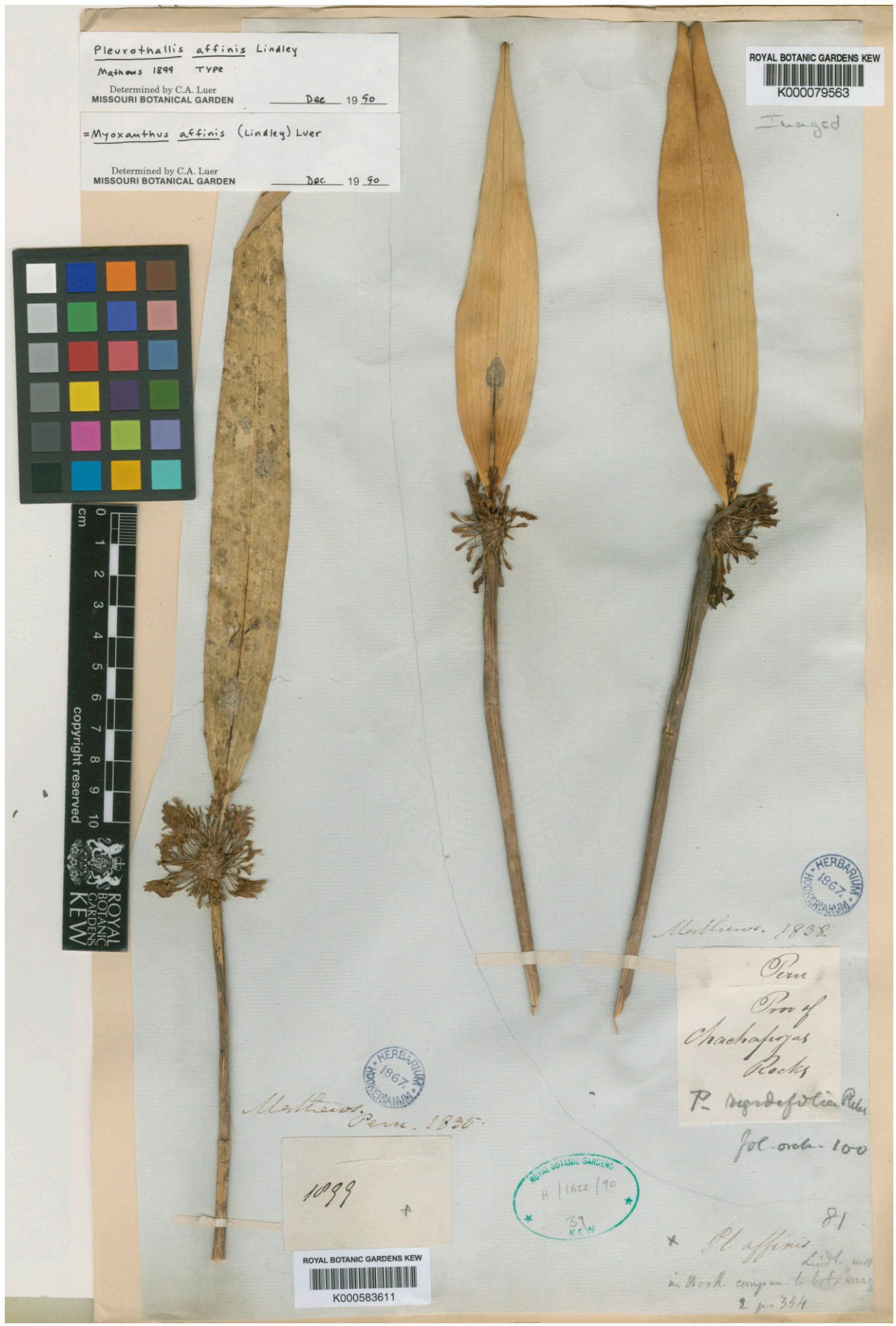

FiguRE 1. Holotype of Pleurothallis affinis Lindl. (三 Myoxanthus affinis) deposited at K. Reproduced with the kind permission of the Director and the Board of Trustees Royal Botanic Gardens, Kew. 


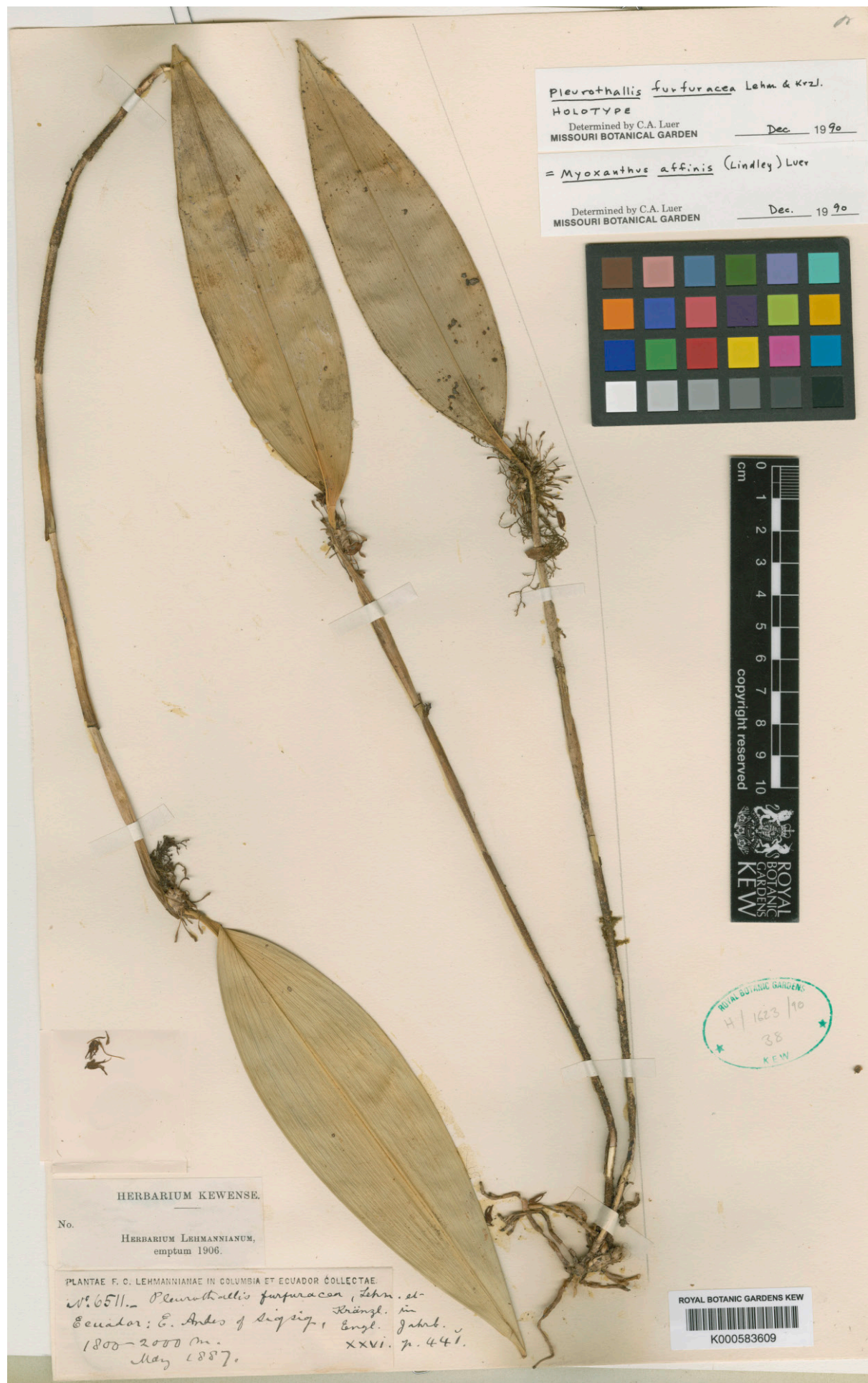

FIguRE 2. Holotype of Pleurothallis furfuracea F.Lehm. \& Kraenzl. (= Myoxanthus affinis), deposited at K. Reproduced with the kind permission of the Director and the Board of Trustees Royal Botanic Gardens, Kew. 
erect, chartaceous, elliptic, acute to shortly acuminate, $15-27 \times 5-10 \mathrm{~cm}$, cuneate basally into a twisted petiole, $1.0-1.5 \mathrm{~cm}$ long. Inflorescences many, emerging from the apex of the ramicaul, enclosed by a papyraceous sheath 6-8 $\mathrm{mm}$ long, appearing successively, several flowering simultaneously, racemose, developing a single flower, the remainder of the raceme vestigial, peduncles persistent and thus becoming subfasciculate with time, $8.0-12.0 \times 0.5 \mathrm{~mm}$, with purple trichomes; floral bracts infundibular, $2-5 \mathrm{~mm}$ long, with purple trichomes, enclosing the pedicel and the base of the ovary; pedicel stout, $2-3 \times 1 \mathrm{~mm}$, with a few purple trichomes. Ovary cylindrical, glandular, $2 \times 1 \mathrm{~mm}$. Sepals greenish-yellow, with a few purple points abaxially; dorsal sepal narrowly ovate, acute, 7.0-9.0 × 2.5-3.0 mm, 5-veined, margins lightly glandular; lateral sepals connate at the base, narrowly ovate, acute, 7.0-9.0 × 1.5-2.0 mm, 4-veined; petals greenish-yellow, translucent basally, narrowly ovatetriangular, acute with apex narrowly rounded, 7.0-9.0 $\times 1.5-2.0 \mathrm{~mm}$, thickened above the middle, conspicuously glandular along the margins, 3-veined; lip white to yellowish, with purple margins, 3-veined, ovatetrilobulate, $2 \times 1 \mathrm{~mm}$, lateral lobes erect, margins serrulate to crenulate, apex obtuse, irregular, sometimes slightly emarginate with an apicule, the disc with a low pair of longitudinal, purple carinae, papillose to verrucose in the center, the base subtruncate, hinged to the apex of the column foot; column greenish-white, winged, stout, semiterete, slightly arched, 2.0-2.5 $\times$ $1.0 \mathrm{~mm}$, irregular and purple at the apex, with a pair of acute teeth, the foot concave, stout, $1 \mathrm{~mm}$ long. Anther cap white, with purple in the middle; $0.5 \times 0.5 \mathrm{~mm}$; pollinia two, yellow, ovoid, laterally flattened, $0.3 \mathrm{~mm}$ wide, with a pair of small, flat, white caudicles.

Note: This description is based only on the Costa Rican material of this species.

Material studied. Costa Rica. Cartago: Jiménez, Pejibaye, La Marta, laderas del Río Gato. Reserva Biológica La Marta, sendero Tepemechines, bosque muy húmedo premontano. $9^{\circ} 46{ }^{\prime} 52^{\prime} \mathrm{N}, 83^{\circ} 41^{\prime} 15^{\prime} \mathrm{W}$, 790 m, 27 de marzo 2016, A. P. Karremans, M. Contreras Fernández, C. Mora, I. Pérez \& J. Velásquez 6990 (JBL-Spirit!; Fig. 3). Cartago: Turrialba, Tayutic, Jicotea, Finca La Pradera. Bosque muy húmedo premontano. 947’06.79” N, 83³2’49.48” W, 1073 m, epífitas en vegetación madura a orillas de una quebrada, 22 de septiembre 2016, G. Rojas-Alvarado, I. Chinchilla, M. Díaz \& A. P. Karremans 69 (JBL-Spirit!; Fig. 4). No additional specimens from Costa Rica were found at JBL, UCR, INB-UCR, USJ or SEL.

Distribution and ecology. Widely distributed from Costa Rica to Peru and Bolivia, where it has been reported to grow at elevations between 350 and 2500 $\mathrm{m}$. In Costa Rica, this large and characteristic species had not been collected until very recently in the premontane very wet forests of Turrialba and Jiménez in Cartago (Fig. 5), a well botanized area where the species has somehow passed overlooked. It flowered in cultivation from December to February.

This species was first collected in Chachapoyas, Peru, by Mathews in 1835, and was described later by Lindley as Pleurothallis affinis. Luer (1992) considered Myoxanthus affinis a variable species and included two other names as synonyms under it. The first, Pleurothallis rigidifolia, was described by Reichenbach in 1855 based on a plant also collected by Mathews in the same locality where he collected the type of $P$. affinis. The second, Pleurothallis furfuracea, was described by Lehmann and Kraenzlin in 1899, based on a plant collected in Ecuador.

Even though there are observable morphological differences between the types of $P$. affinis, $P$. rigidifolia and especially $P$. furfuracea, the original descriptions of the first two are too vague to allow for a detailed comparison. Across the wide range of this species it seems to be quite variable, and there is apparently little consistency in some of the diagnostic features that could be used to distinguish them. At Selby there are several sketches of diverse individuals of this species prepared by Luer, and illustrations by other authors have appeared in several local floras. The illustrations clearly show variation in the presence and absence of trichomes on the sepals, the shape and ornamentation of margins of the petals, the shape of the lip and the ornamentation of the apex of the column, and none seem to be consistent. Especially outstanding is the variation in the width of the leaf. The Costa Rican material (Fig. 3-4) consistently has very broad, chartaceous leaves, quite unlike those of type specimen from Peru (Fig. 1). Nevertheless, the type specimen of P. furfuracea from Ecuador (Fig. 2) shows a habit much like that of the Costa Rican specimens il- 


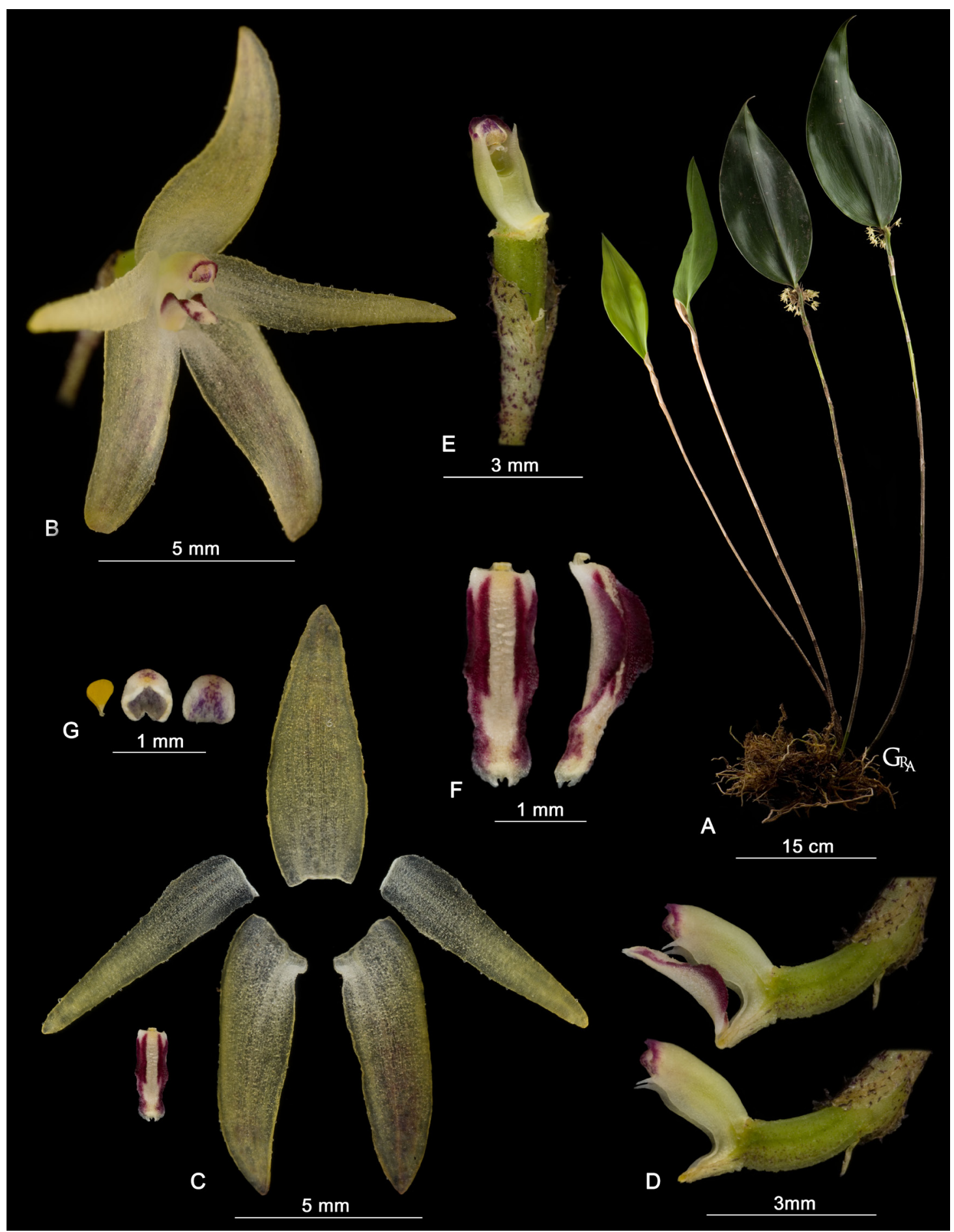

Figure 3. Lankester Composite Dissection Plate (LCDP) of Myoxanthus affinis. A. Habit. B. Flower. C. Dissected perianth. D. Column in lateral view with and without lip. E. Column in ventral view. F. Lip. G. Pollinia and anther cap. Photographs by G. Rojas-Alvarado based on A. P. Karremans 6990 (JBL-Spirit). 


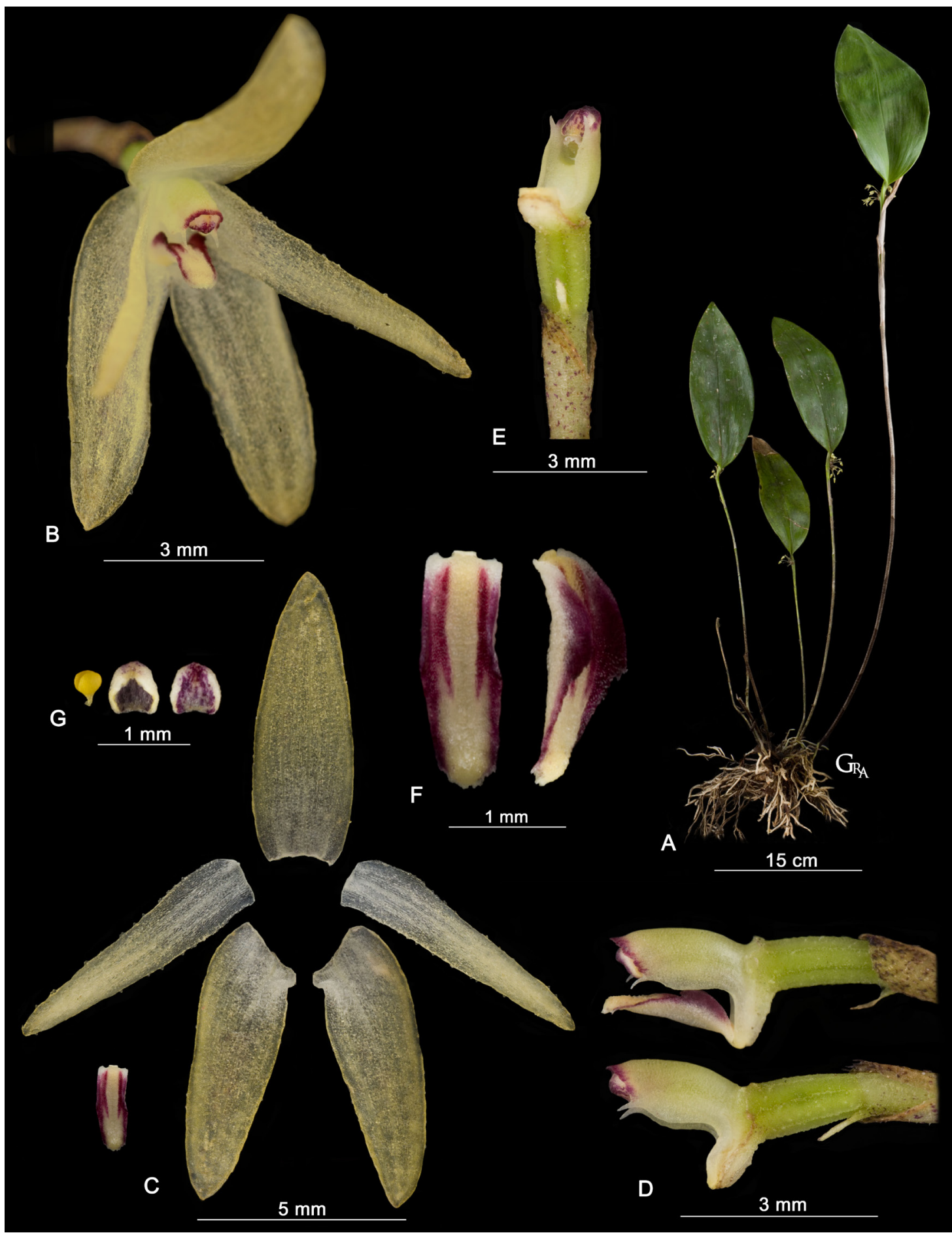

FIgURE 4. Lankester Composite Dissection Plate (LCDP) of Myoxanthus affinis. A. Habit. B. Flower. C. Dissected perianth. D. Column in lateral view with and without lip. E. Column in ventral view. F. Lip. G. Pollinarium and anther cap. Photographs by G. Rojas-Alvarado based on G. Rojas-Alvarado 69 (JBL-Spirit). 


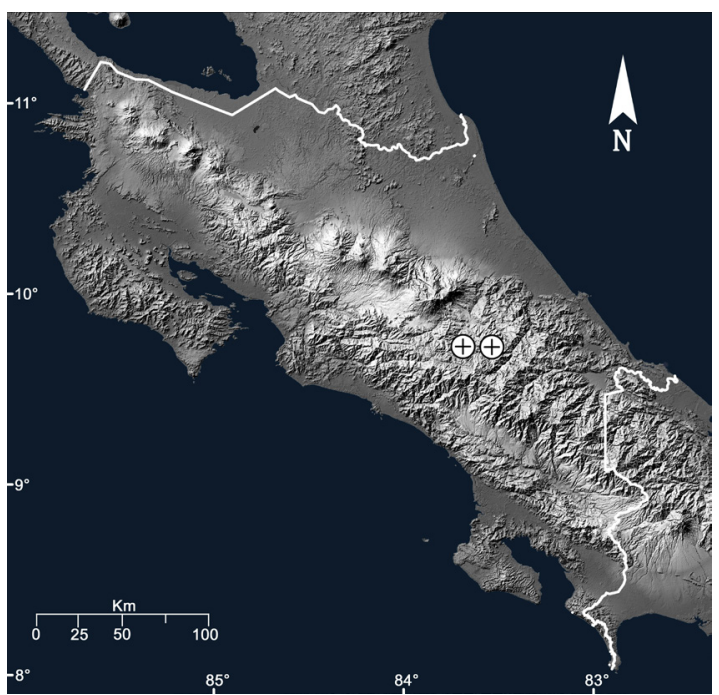

FIGURE 5. Distribution map of Myoxanthus affinis (Lindl.)

Luer in Costa Rica.

lustrated here, and we have no doubt that they represent the same species. It is possible that more than a single species are currently treated under the name M. affinis, but we concur with Luer that at this time it is impossible to set these entities apart.

In Costa Rica, Myoxanthus affinis is easily distinguished from all other Myoxanthus species by its outstanding vegetative features. It is the only species with ramicauls that reach up to $70 \mathrm{~cm}$ tall, bearing large, chartaceous, elliptic leaves. The less developed stems of $M$. affinis are rivaled in size only by well developed plants of Myoxanthus cereus (Ames) Luer ex RojasAlv. \& Karremans, which is also treated here. But the latter can be easily distinguished by its coriaceous leaves ( $v s$. chartaceous leaves), sheaths of the ramicaul with shedding trichomes (vs. sheaths of the ramicaul with persistent trichomes), flowers with ovary $5-6 \mathrm{~mm}$ long ( $v s$. ovary $2 \mathrm{~mm}$ long), peduncles $1-2 \mathrm{~mm}$ long (vs. peduncles 8-12 mm long) sepals oblong-ovate and obtuse ( $v s$. sepals narrowly ovate and acute), and petals glabrous (vs. petals with glandular margins).

Myoxanthus cereus (Ames) Luer ex Rojas-Alv. \& Karremans, comb. nov.

Bas.: Pleurothallis cerea Ames, Schedul. Orchid. 4: 19, 1923.

TYPE: Costa Rica. Provincia de Cartago: Agua Ca- liente, C. H. Lankester 358 (holotype, K; photo of type!; illustration of type, AMES!; Fig. 6).

Plant medium, epiphytic, subcaespitose, rhizome stout, covered by hispidulous sheaths. Roots flexuous, branching, 1-3 mm in diameter. Ramicauls stout, erect, up to $45 \mathrm{~cm}$ long, 3-5 $\mathrm{mm}$ in diameter, thicker basally, enclosed by overlapping, tubular sheaths. Sheaths light brown to whitish, papyraceous, 5-9 cm long, with dark trichomes disposed in rows perpendicular to the ramicaul axis, deciduous leaving scars. Leaf coriaceous, elliptic, acute, $17.0-23.0 \times 4.5-7.5 \mathrm{~cm}$, cuneate basally into a $1 \mathrm{~cm}$ long petiole. Inflorescences many, emerging from the apex of the ramicaul, appearing successively, several flowering simultaneously, racemose, developing a single flower, the remainder of the raceme vestigial, peduncles persistent and thus becoming subfasciculate with time, 1-2 mm long; floral bracts infundibular, with purple trichomes, 3-6 $\mathrm{mm}$ long, enclosing the pedicel; pedicel stout, 3-4 $\mathrm{mm}$ long. Ovary cylindrical, glandular, 5.0-6.0 $\times$ $1.0-1.5 \mathrm{~mm}$. Sepals white to cream above the middle, 3-veined, glabrous, thickened above the middle, dorsal sepal oblong-obovate, obtuse, 10.0-10.5 × 3.0-3.5 $\mathrm{mm}, 3$-veined, lateral sepals free to connate only at the base, oblong-ovate, obtuse, 8.0-9.0 × 2.5-3.0 mm, petals white to cream, glabrous, narrowly oblong-ovate, obtuse, $9.0 \times 2.0-2.5 \mathrm{~mm}$, thickened above the middle, 3 -veined; lip white, with purple margins, oblong, $2 \times$ $1 \mathrm{~mm}, 3$-veined, apex obtuse, apiculate, the disc with a minute pair of longitudinal lamellae in the middle, papillose-verrucose in the center, the base truncate, hinged on the apex of the column foot; column white, winged, stout, semiterete, $2 \times 1 \mathrm{~mm}$, apex with a pair of acute teeth, the foot concave, stout, $1 \mathrm{~mm}$ long, with light purple at the apex. Anther cap purple with white margins, granular, apex verruculose, $0.6 \times 0.5 \mathrm{~mm}$, pollinia two, yellow, ovoid, laterally flattened, $0.3 \mathrm{~mm}$ wide, with a pair of small, flat, white caudicles.

Material studied. Costa Rica. Cartago: Turrialba, Tayutic, Platanillo. En bosque alterado y árboles solitarios en la laderas del Río Platanillo. Bosque muy húmedo premontano. 9०48'21.20" N, 83॰33'21.31' 'W, 974 m, 11 de agosto del 2012, A. P. Karremans, B. Gravendeel, J. Kruizinga 5693 (JBL-Spirit!; Fig. 7). Cartago: Turrialba, Santa Cruz. Después de La Pastora. Desde el puente sobre el Río Turrialba hasta unas cataratas 


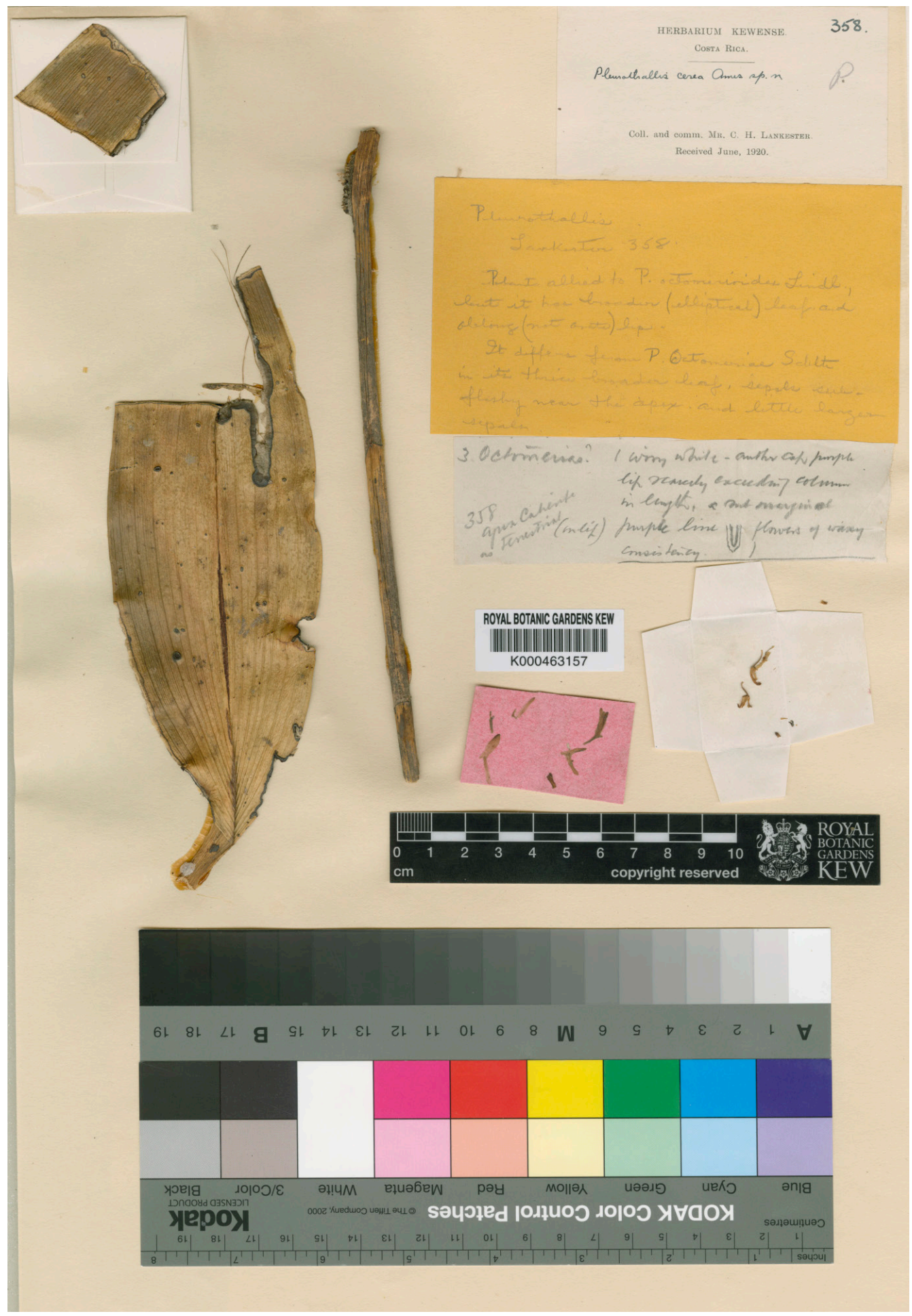

FiguRe 6. Holotype of Pleurothallis cerea Ames (三 Myoxanthus cereus), deposited at K. Reproduced with the kind permission of the Director and the Board of Trustees Royal Botanic Gardens, Kew. 


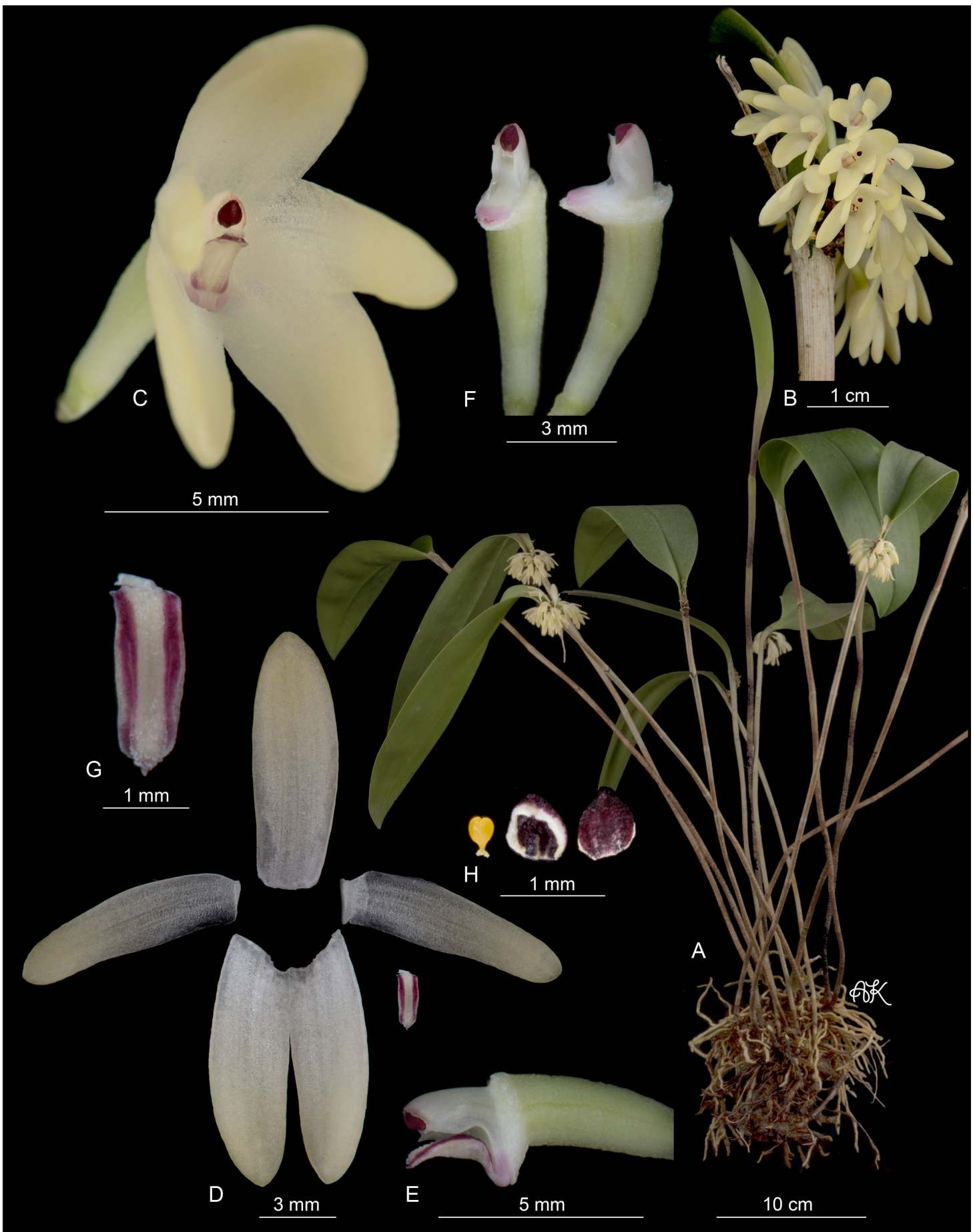

Figure 7. Lankester Composite Dissection Plate (LCDP) of Myoxanthus cereus (Ames) Luer ex Rojas-Alv. \& Karremans. A. Habit. B. Inflorescence. C. Flower. D. Dissected perianth. E. Column with lip, lateral view. F. Column without lip, ventral and lateral view. G. Lip. H. Pollinarium and anther cap. Photographs by A.P. Karremans and G. Rojas-Alvarado based on A. P. Karremans 5693 (JBL-Spirit). 
sobre el Río. 957'16" N, 8346’12”'W, 1800 m, 31 de enero 2005, A. P. Karremans 754 (JBL-Spirit!). Cartago: Cartago, San Nicolás, Cerros la Carpintera, Campo Iztarú. Bosque remanente. 953'18.1' N, 8358'08.0” W, 1750 m, 26 de octubre 2014, A. Cascante 2444 (USJ!; Fig. 8). Costa Rica. Without further collection data, 14 de noviembre 1978, Mora de Retana s.n. (USJ!). Costa Rica. Without further collection data, $A$. Endrés s.n. (W-0019911!).

Distribution AND ECOLOGY. This species is current only known from a few localities around Cartago in Costa Rica. It is found as an epiphyte in lower montane and premontane very wet forest, at elevations between 974 and $1800 \mathrm{~m}$ (Fig. 9). It flowered in cultivation from December to April.

The type specimen of Pleurothallis cerea Ames was collected by Charles Lankester in Cartago, Costa Rica, and described by Oakes Ames in 1923. Luer (1992) placed $P$. cerea under the synonymy of Myoxanthus octomeriae, a species based on a plant collected by Powell from Panama. Nevertheless, Luer did note differences between the two species, and in 1991 annotated a specimen collected by Endrés from Costa Rica as " $M$. cereus (Ames) Luer", a combinationwhich he never published. When Soto (2008) revised the taxonomy of the Mexican Myoxanthus, he reduced $M$. octomeriae, with all its synonyms, to the synonymy of the older $M$. congestus, a name based on material from Mexico. However, he also noted the odd features of $P$. cerea, especially in the size and shape of the leaf and in the lip structure.

Here we formally recognize the distinctness of $M$. cereus from $M$. congestus (= M. octomeriae), both of which are found in Costa Rica. Myoxanthus cereus is distinguished from $M$. congestus by the larger, elliptic leaves $17.0-23.0 \times 4.5-7.5 \mathrm{~cm}$ (vs. smaller, narrowly elliptic $5.0-15.0 \times 2.0-4.5 \mathrm{~cm})$, sepals oblong, obtuse and glabrous (vs. ovate, acute with minute warts externally), lip apex obtuse, apiculate, with a pair of longitudinal lamellae in the middle (vs. lip apex acute, without an apicule, lacking lamellae), anther cap shortly verrucose at the apex (vs. anther cap conspicuously dorsally papillose). Myoxanthus cereus is apparently endemic to the Atlantic watershed of the mountains of the Central Valley in the province of Cartago, where it is found growing above $1000 \mathrm{~m}$ in elevation. It has not been found growing sympatrically with $M$. congestus,

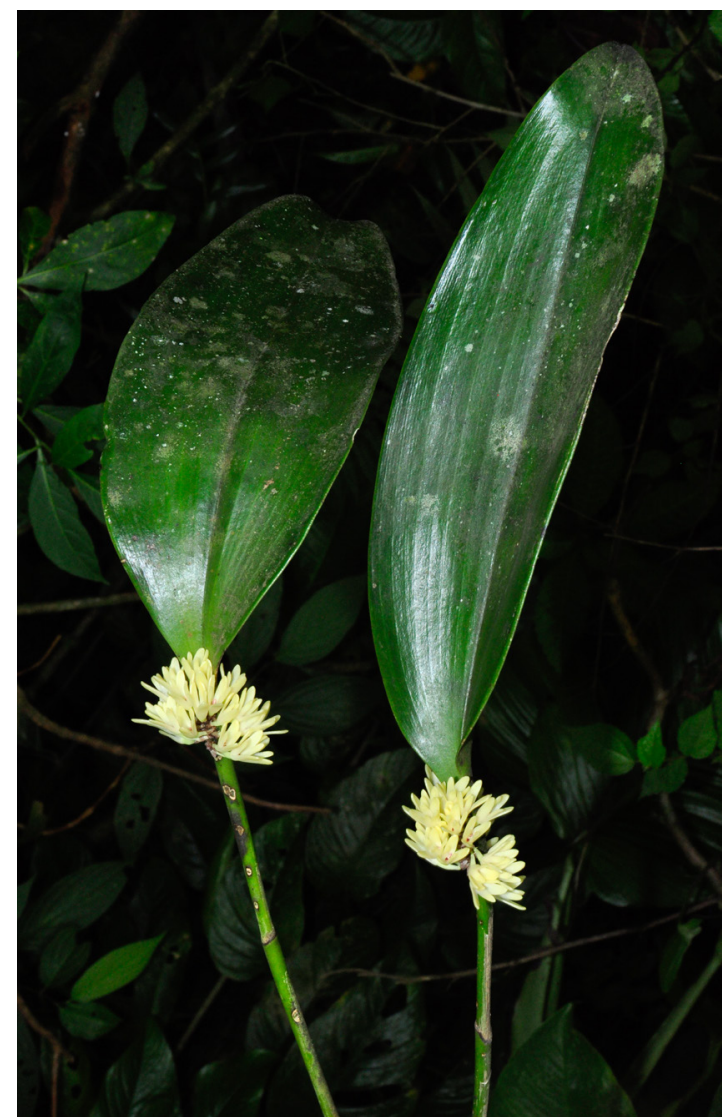

FIgURE 8. Myoxanthus cereus photographed in situ at La Carpintera (A. Cascante 2444). Photograph by A. Cascante, reproduced with his kind permission.

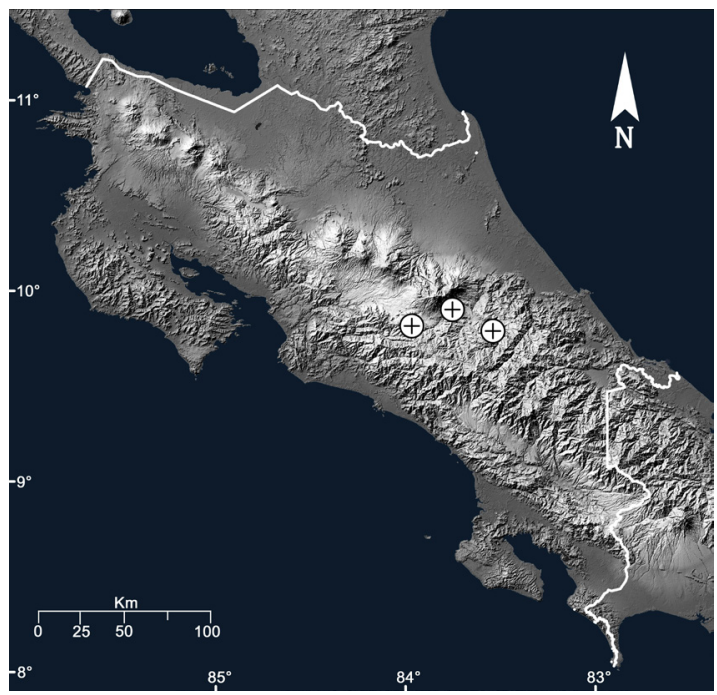

Figure 9. Distribution map of Myoxanthus cereus (Ames) Luer ex Rojas-Alv. \& Karremans in Costa Rica. 
a species that is more commonly found at lower elevations on both Atlantic and Pacific watersheds of the Costa Rican mountain chains.

ACKNOWLEDGMENTS. This manuscript was prepared as part of a dedicatory issue commemorating the 95th birthday of Carl Luer, whose extensive work on the Pleurothallidinae is the basis for most current studies in the subtribe, including the present. We owe many thanks to the staff at Selby, especially Bruce Holst, Antonio Toscano de Brito and Elizabeth Gandy, for their help in accessing relevant literature and key herbarium specimens. Alfredo Cascante and Christian Trejos are thanked for their photographic material and their help with access to the material kept at USJ. Three anonymous reviewers have improved the manuscript substantially and are thanked. We are thankful to the Ministerio del Ambiente y Energía de Costa Rica (MINAE) and its Sistema Nacional de Áreas de Conservación (SINAC) for issuing the scientific permits under which wild specimens were collected. We thank the Vice-Presidency of Research of the University of Costa Rica for providing support through the project: "Técnicas moleculares para resolver la sistemática de los géneros Myoxanthus y Octomeria (Orchidaceae) en Costa Rica.

\section{LitERATURE CITED}

Barbosa Rodrigues, J. (1882) Genera et species Orchidearum Novarum, II. Sebastianopolis, Brazil, 222 pp.

Cogniaux, A. (1896) Orchidaceae, in Urban, Flora Brasiliensis, 3(4), 672 pp.

Karremans, A. P. (2016). Genera Pleurothallidinarum: an updated phylogenetic overview of Pleurothallidinae. Lankesteriana, 16(2), 219-241.

Karsten, H. (1847). Die Duboisia reymondii H.Karst. Allg. Gartenzeitung (Otto \& Dietrich) 15, 394.

Karsten, H. (1848). Beschreibung einiger neuen Pflanzengattun gen. Duboisia-reymondia palpigera H.Karst. Bot. Zeitung (Berlin), 6, 397, 398.

Lindley, J. (1836). Notes upon some genera and species of American Orchidaceae. Companion to the Botanical Magazine. 2, 353-357.

Luer, C. A. (1982). A reevaluation of the genus Myoxanthus (Orchidaceae). Selbyana, 7(1), 34-54.

Luer, C. A. (1986). Icones Pleurothallidinarum I. Systematics of Pleurothallidinae (Orchidaceae). Monographs in Systematic Botany from the Missouri Botanical Garden, 15.
Luer, C. A. (1992). Icones Pleurothallidinarum IX. Systematic of Myoxanthus. Addenda to Platystele, Pleurothallis, subgenus Scopula and Scaphosepalum (Orchidaceae). Monographs in Systematic Botany from the Missouri Botanical Garden, 44, $1-128$.

Luer, C. A. (1995). A re-evaluation of the Pleurothallid subgenera Satyria and Silenia (Orchidaceae). Monographs in Systematic Botany from the Missouri Botanical Garden, 57, 146.

Luer, C. A. (2003). Orchidaceae. In: Hammel, B. E. Grayum, M. H. Herrera, C. \& Zamora, N. Manual de plantas de Costa Rica. Vol. 3. Monocotiledóneas (Orchidaceae-Zingiberaceae). Monographs in Systematic Botany from the Missouri Botanical Garden (pp. 339-342).

Poeppig, E. F., \& Endlicher, E, F. (1835). Nova Genera ac Species Plantarum, quas in regno Chilensi Peruviano et in terra Amazonica, 1, 100.

Pridgeon, A. M. (2005). Subtribe Pleurothallidinae. Pridgeon, A. M. Cribb, P. J. Chase, M. W. Rasmussen, F. N. (Eds.). Genera Orchidacearum. Vol. 4 Epidendroideae (Part One). Oxford: Oxford University Press (pp. 370-373).

Pridgeon, A. M., \& Chase, M. W. (2002). Nomenclatural notes on Pleurothallidinae (Orchidaceae). Lindleyana, 17(2), 98-101.

Pridgeon, A. M., \& Stern, W. L. (1982). Vegetative anatomy of Myoxanthus. Selbyana, 7(1), 55-63.

Pridgeon, A. M., Solano, R. \& Chase, M. W. (2001). Phylogenetic relationships in Pleurothallidinae (Orchidaceae): combined evidence from nuclear and plastid DNA sequences. American Journal of Botany, 88, 2286-2308.

Pupulin, F. (2002). Catálogo revisado y anotado de las Orchidaceae de Costa Rica. Lankesteriana, 4, $1-88$.

Pupulin, F., Bogarín, D., \& Fernández, M. (2010). On the identity of Myoxanthus scandens (Orchidaceae: Pleurothallidinae), with a new species from Costa Rica. Lankesteriana, 9(3), 467-473.

Reichenbach, H. (1852). Pleurothallis reymondii (H. Karst.) Rchb.f., Ann. Bot. Syst. (Walpers), 3(3), 520.

Soto Arenas, M. A. (2008). Myoxanthus congestus. In: Hágsater, E., \& Soto, A. (Eds.), Icones Orchidacearum, fascicle 10: Orchids of Mexico, Parte 4. 